DOI: http://dx.doi.org/10.12775/SE.2019.0038

Uniwersytet Mikołaja Kopernika w Toruniu,

kontakt:p.chlopek@doktorant.umk.pl,

ORCID ID: 0000-0001-5565-7761

Sztuka Edycji 2/2019

ISSN 2084-7963 (print)

ISSN 2391-7903 (online)

s. $180-184$

\section{Patryk Chtopek}

Intymistyka 2.0 dokumentów może działać jak przyzwolenie na dogłębne analizy. Autor z kolei sam z siebie nie może zaoponować i powstrzymać postronnych przed zapoznaniem się z materią nieprzeznaczoną do ujawnienia. Wiele dokumentów zostało zniszczonych przez autorów właśnie w obawie przed tym, że zapiski trafią w niepowołane ręce. Elżbieta Neyman w wydaniu korespondencji Marii i Stanisława Ossowskich wspomina: „Byłam świadkiem, kiedy Maria Ossowska systematycznie niszczyła własny dziennik (obejmujący z górą 50 lat)" ${ }^{2}$. Znany jest również przykład korespondencji Witkacego ze swoją żoną, gdzie autor Pożegnania jesieni, mający świadomość weredycznego charakteru swoich listów, prosi małżonkę o ich zniszczenie w obawie przed ich wydaniem w przyszłości ${ }^{3}$. Inni artyści zabezpieczają się przed taką ewentualnością odpowiednimi zapisami w testamencie, jak Maria Dąbrowska, która zastrzegła, że jej dzienniki w całości mogą ukazać się dopiero czterdzieści lat po jej śmierci.

Ta refleksja może determinować pytanie: czy wartość merytoryczna, historyczna lub biograficzna danego tekstu jest na tyle ważna, że można narazić twórców i ich rodziny na skandal oraz obciążyć nasze indywidualne sumienie?

Pytanie to jest istotne, gdyż wraz z rozwojem technologicznym spisywanie dzienników, pamiętników, a przede wszystkim wymiana korespondencji coraz częściej (a w przypadku tego ostatniego - w olbrzymiej większości) prowadzone są za pomocą elektroniki. Codziennymi narzędziami pracy pisarza nie są już kartka i długopis - akcesoria te zostały zastąpione przez programy do edycji tekstu, takie jak Word i OpenOffice, z kolei tradycyjny list został wyparty przez SMS-y, e-maile, komunikatory (m.in. Messenger, Skype) oraz coraz popularniejsze portale społecznościowe. Jakie przynosi to zmiany dla badacza, który chciałby sporząazić publikację opartą na korespondencji elektronicznej np. Olgi Tokarczuk? Różnice będą znaczące, o ile podjęcie takiego przedsięwzięcia w ogóle okaże się możliwe, nie tylko ze względów prawnych czy moralnych, ale również czysto technicznych.

Oczywiście postępująca cyfryzacja naszego życia nie oznacza, że współcześni autorzy nie prowadzą tradycyjnych zapisków lub tradycyjnej korespondencji. Nie zachęcam także do odchodzenia od wydawania „klasycznej” intymistyki. Swoim artykułem chcę zwrócić uwagę na specyfikę dzisiejszej sytuacji. Jest to refleksja na temat tego, jak wykorzystywana przez nas technologia wpłynęła w bardzo krótkim czasie na nasze życie. Swoimi rozważaniami spróbuję ustalić, czy praca nad zdygitalizowanymi tekstami intymistycznymi zapiski autora. Brak przeszkód przed poznaniem zawartości 
jest w ogóle możliwa, a jeżeli jest, to czy powinna być podejmowana.

\section{Uniwersyteckie zajęcia z „hakerstwa”?}

Swój wywód, może dosyć przewrotnie, zacznę od stwierdzenia, że pozyskiwanie materiałów należących do sfery cudzej prywatności, nawet do celów badawczych, jest dzisiaj uważane za nielegalne, a przynajmniej w zakresie, który chcę tutaj omówić. Otóż podążając za czystą logiką - by uzyskać dostęp do takich materiałów, badacz musiałby najpierw uzyskać dostęp do zaszyfrowanych najczęściej źródeł, takich jak komputer, konto e-mailowe itp. Próba złamania hasła dostępu jest powszechnie uznawana za atak hakerski i regulowana przez polski kodeks karny w następujący sposób:

Art. $267 \$ 1$. Kto bez uprawnienia uzyskuje dostęp do informacji dla niego nieprzeznaczonej, otwierając zamknięte pismo, podłączając się do sieci telekomunikacyjnej lub przełamując albo omijając elektroniczne, magnetyczne, informatyczne lub inne szczególne jej zabezpieczenie, podlega grzywnie, karze ograniczenia wolności albo pozbawienia wolności do lat 2 .

$\$ 2$. Tej samej karze podlega, kto bez uprawnienia uzyskuje dostęp do całości lub części systemu informatycznego.

$\$ 3$. Tej samej karze podlega, kto w celu uzyskania informacji, do której nie jest uprawniony, zakłada lub posługuje się urządzeniem podsłuchowym, wizualnym albo innym urządzeniem lub oprogramowaniem.

$\$ 4$. Tej samej karze podlega, kto informację uzyskaną w sposób określony w $\$ 1-3$ ujawnia innej osobie.

$\$ 5$. Ściganie przestępstwa określonego w $\$ 1-4$ następuje na wniosek pokrzywdzonego ${ }^{4}$.

W związku z przytoczonym artykułem chciałbym zwrócić uwagę na dwie kwestie: po pierwsze, tak jak wspominałem, artykuł znajduje się w kodeksie karnym. To oznacza, że przejaw hakerstwa, za który można uznać złamanie hasła do komputera domowego lub poczty elektronicznej, w obliczu prawa nie jest traktowany jako zwykłe wykroczenie, a przestępstwo, i może grozić pozbawieniem wolności. Po drugie, mamy jednak do czynienia również z $\$ 5$ tego artykułu, który wskazuje konieczność zgłoszenia popełnionego przestępstwa przez pokrzywdzonego. Przytoczony paragraf informuje nas o tym, że jest to tzw. przestępstwo wnioskowe, gdzie uprawnionym do wytoczenia powództwa jest jedynie pokrzywdzony. Jeżeli z jakiegoś powodu pokrzywdzony nie może wnieść oskarżenia, np. ze względu na swoją śmierć, wówczas sąd odmawia wszczęcia postępowania, jeżeli przestępstwo zostanie zgłoszone przez inną osobę (np. krewnych), zgodnie $\mathrm{z}$ art. $17 \$ 1$ punktem 10 kodeksu postępowania karnego:

Art. $17 \$ 1$. Nie wszczyna się postępowania, a wszczęte umarza, gdy:

[...]

10) brak wymaganego zezwolenia na ściganie lub wniosku o ściganie pochodzącego od osoby uprawnionej, chyba że ustawa stanowi inaczej ${ }^{5}$.

W tej sytuacji znów należy pamiętać o dwóch kwestiach: po pierwsze, nawet w przypadku, w którym działalność badacza nie zostanie raczej zgłoszona do odpowiedniej instancji prawnej przez pokrzywdzonego, wciąż pozostaje ona przestępstwem. Istnieje prawdopodobieństwo, że sąd postąpi w szczególny sposób i mimo wszystko dojdzie do wszczęcia postępowania karnego. Po drugie, należy pamiętać, że pokrzywdzoną w sprawie może być również osoba, z którą autor prowadził korespondencję. Gdy dowie się ona o prowadzonym przez badacza procederze, ma prawo zgłosić go do sądu na podstawie art. $267 \mathrm{kk}$.

Oczywiście, materiały mogą zostać przekazane badaczowi przez spadkobierców artysty, lecz trzeba tu postawić pytanie czy elektroniczne dane w postaci korespondencji e-mailowej lub postów publikowanych na portalach społecznościowych są dziedziczne? Możemy sobie również wyobrazić sytuację, w której dostajemy pozwolenie na korzystanie z materiałów, jednak spadkobiercy nie znają haseł dostępu do używanych przez artystę urządzeń. Odpowiadając na pytanie z tytułu tej części tekstu, kształcenie hakerów w murach uniwersytetu nie jest możliwe, przede wszystkim ze względu na to, że jest to nielegalny proceder. W tej sytuacji podstawowe pytanie, na które musielibyśmy odpowiedzieć, brzmi: czy powinniśmy zarzucić możliwość tworzenia wydań materiałów cyfrowych o charakterze intymnym?

Kwestie moralne oraz opór przed możliwością popełnienia przestępstwa z pewnością mogą powstrzymać nas przed próbą stworzenia publikacji opierającej się na materiałach pochodzących z zaszyfrowanych urządzeń elektronicznych lub kont internetowych. Nie musimy jednak wykluczać, że w przyszłości takie prace zostaną w jakiś sposób umożliwione. Jednym z rozwiązań mogłoby być korzystanie z usług informatyków, którzy współpracowaliby z filologiem, łamiąc 
kolejne hasła, jednak i tu z pewnością spotkalibyśmy się z oporami moralnymi. Wciąż jednak istnieje ewentualność, że badania tego typu będą mogły być prowadzone na prośbę i za zgodą autora. Na potrzeby artykułu przyjmijmy więc, że moje rozważania są prowadzone z myślą o udostępnieniu przez osoby za to odpowiedzialne prywatnego sprzętu oraz haseł autora koniecznych do zapoznania się ze zdygitalizowanymi materiałami.

\section{Jakie mamy możliwości?}

W to, że publikacje o charakterze intymistycznym będą pojawiać się na rynku, nie można wątpić. Dzisiaj na rynku wydawniczym możemy znaleźć książki współczesnych artystów wydających swoje prywatne zapiski. Do takich dzieł zaliczymy m.in. Wieloryby i ćmy Szczepana Twardocha, Rzeczy utracone Eukasza Orbitowskiego lub Wiadomość z nieba Keith i Brooke Desserich. Abstrahując od wartości literackiej tych dzieł, należy domniemywać, że o ile możemy wierzyć w uczciwe intencje ich autorów, zapiski były sporządzane bez intencji ich późniejszego wydania. Są to dokumenty zdające relacje z osobistych przeżyć lub przemyśleń pisarzy. Nie są to jednak przypadki, które z edytorskiego punktu widzenia mogłyby być dla nas (na tę chwilę) atrakcyjne. Przede wszystkim mamy tu do czynienia z sytuacją, gdzie autor ma pełną kontrolę nad procesem wydawniczym książki, w związku z tym jej treść jest przez niego autoryzowana.

Takiej możliwości nie miał np. Ryszard Kapuściński, którego kontrowersyjna biografia autorstwa Artura Domosławskiego ukazała się w Polsce w 2010 roku. Sprawa jest o tyle oburzająca, że wydanie ukazało się mimo jawnego protestu żony autora Cesarza, która nie zgadzając się na sposób przedstawienia wątków obyczajowych w książce, próbowała powstrzymać jej publikację za pośrednictwem sądu ${ }^{6}$. Jednym z najpoważniejszych zastrzeżeń wobec Domosławskiego była manipulacja otrzymanym materiałem dla nadania kontrowersyjności, a co za tym idzie - większej poczytności książce. Chęć odnoszenia korzyści majątkowych nie zawsze jest tłumiona przez poczucie etyki. Właśnie z tego względu wielu autorów wolało niszczyć swoje notatki i korespondencję.

Z internetem, czy też elektroniką ogólnie, sprawa ma się jednak inaczej, ponieważ o ile aktywnie działamy w sieci, bardzo trudno jest ślady naszej działalności całkowicie z niej usunąć. Nawet jeżeli kasujemy treści z pierwotnego miejsca ich umieszczenia, informacje wciąż pozostają w cyberprzestrzeni, a to ze względu na praktycznie nieograniczone obecnie możliwości przechowywania danych. By dobrze zobrazować skalę tego procederu, wystarczy informacja, że do późniejszych analiz rynkowych duże firmy (najczęściej za naszą zgodą wyrażoną przez akceptację regulaminu korzystania z witryny) przechowują nie tylko treści przez nas publikowane, ale nawet historię wyszukiwanych hasel, przeglądanych stron, a istnieją także przesłanki, że rejestrowany może być też ruch kursora ${ }^{7}$. Wykwalifikowany informatyk jest w stanie przywrócić usunięte przez nas pliki nawet po wielokrotnym formatowaniu dysku twardego. Możemy więc czysto hipotetycznie założyć, że prawdopodobne jest dotarcie do większości treści opublikowanych przez konkretnego użytkownika w internecie i do dużej części plików przechowywanych na jego urządzeniach elektronicznych.

Inną wartą rozważenia kwestią jest to, czy zbieranie materiałów publikowanych $\mathrm{w}$ ciągu życia przez autora $\mathrm{w}$ internecie lub zapisanych na urządzeniach elektronicznych jest opłacalnym z badawczego punktu widzenia przedsięwzięciem. Wiązałoby się ono z nakładem tytanicznej pracy, która mogłaby nie przynieść wymiernych korzyści naukowych. Obecnie dla wielu osób poczucie swobody i nieograniczenia w stosowaniu „wirtualnych kartek” wiąże się z możliwością pomnażania mało istotnych informacji na nośnikach elektronicznych. W XIX wieku, jak zapewne możemy sobie wyobrazić, pusta karta była traktowana z większym pietyzmem, autor intensywniej kalkulował wartość zapisywanych na niej słów. To, rzecz jasna, przekładało się na jakość zachowanych do naszych czasów dokumentów. Jak też łatwo możemy się domyślić, upowszechnienie materiału gotowego w każdej chwili do zapisania i wygodnego do archiwizowania spowodowało ogólny jakościowy regres. Edytorowi, który podejmie się wyzwania opracowania „elektronicznej intymistyki” nowoczesnego autora, pozostanie więc selekcja zastanego materiału. Podstawowym zadaniem, z którym musiałby się w takiej sytuacji zmierzyć, będzie, oprócz ustalenia celu publikacji, odsiew treści nieprzedstawiających jakiejkolwiek wartości.

Oszacowanie jednak tego, co warto byłoby wydawać, jest trudne, zależałoby przede wszystkim od projektu naukowego. $Z$ pewnością portale recenzyjne, jak lubimyczytac.pl, filmweb.pl, lub strony gromadzące dane o przesłuchanych utworach muzycznych, np. last.fm, pomogłyby (o ile autor z takich stron korzystał) w zaobserwowaniu gustów i ich ewolucji na przestrzeni lat. Strony te oferują możliwość oceny utworu literackiego, filmowego lub muzycznego w prostej skali (1-10) oraz napisanie opinii. Prowadzone przez autora konto na jednym z takich portali mogłoby być bogatym źródłem informacji na temat jego artystycznych upodobań czy 
też nawet ich rozwoju. Wartość zebranych informacji, choćby w postaci danych statystycznych, byłaby z pewnością niemała, przy czym nie wiązałoby się to ze szczególnym naruszeniem prywatności twórcy.

Za ważne źródło informacji można z pewnością uznać prywatny smartfon lub komputer autora, ewentualnie dysk twardy urządzenia, na którym byłyby przechowywane potrzebne badaczowi materiały. Dostęp do takiego sprzętu jest o tyle cenny, że pozwala na eksplorowanie plików, wśród których moglibyśmy znaleźć niepublikowane teksty lub wczesne wersje dzieł autora. Osobista elektronika jest przede wszystkim skarbnicą naszej prywatności. Na coraz pojemniejszych nośnikach pamięci przechowujemy zdjęcia, filmy, muzykę, często zapisujemy w systemowym notatniku lub kalendarzu ważne dla nas wydarzenia, jak też harmonogram naszych zajęć. Różnorodność materiału jest bardzo duża i o wiele łatwiej można doprowadzić do nadużycia. By nie upublicznić treści, które mogłyby doprowadzić do zniesławienia autora, należałoby określić ścisłą granicę w badaniach.

Zasada ta tyczy się również pracy ze współczesną korespondencją, która może być mocno zróżnicowana. Szczególną uwagę warto poświęcić wiadomościom o nieformalnym charakterze wymienianym z osobami z najbliższego otoczenia autora, najczęściej za pośrednictwem chatów. Podobnie jak w przypadku przytaczanych „wirtualnych kartek”, również $\mathrm{w}$ sferze prywatnej komunikacji doszło do oswobodzenia presji związanej z oszczędnością materiału, co z kolei pozwoliło na upodobnienie się wymiany elektronicznej korespondencji do odbywanej w cztery oczy dyskusji. Większą wartość historyczną czy artystyczną z pewnością przypiszemy poczcie tradycyjnej, nie powinniśmy jednak bagatelizować potencjalnej wartości nowoczesnej komunikacji chociażby w kontekście biograficznym.

Należy też zastanowić się nad klasyfikacją wpisów na portalach społecznościowych publikowanych za pośrednictwem prywatnych, niesłużących celom marketingowym kont. Tekstów tych z jednej strony nie można uznać za stricte intymne, kierowane są bowiem do większego grona odbiorców. Z drugiej jednak strony jest to grupa zamknięta, zorganizowana przez autora, a więc obejmująca osoby, z którymi ma on bądź miał bliższe relacje. Podobny charakter przekazu informacji za pomocą , analogowych" metod z pewnością nie byłby najłatwiejszym zadaniem. Anonse prasowe chociażby trafiały zazwyczaj do większej liczby czytelników, często nieznanych autorowi, miały one określoną formę, charakteryzowały się zwięzłością z uwagi na potrzebę szczególnej oszczędności miejsca na stronie. Post na portalu społecznościowym z kolei nie musi ograniczać inwencji autora, daje pełną swobodę w zakresie objętości tekstu, jego tematu oraz odbiorców.

Zdarzają się oczywiście przypadki, w których autor umożliwia przeglądanie swoich postów również osobom spoza określonej przez siebie grupy odbiorców. Dzięki temu wielbiciele twórczości artysty mogą w pewnym stopniu obserwować elementy jego codzienności. O tym, że publiczne posty na portalach społecznościowych również potrafią mieć prywatny charakter, możemy przekonać się, wchodząc na profil Łukasza Orbitowskiego, który podzielił się taką informacją:

Ponieważ źle spałem i średnio się mam, to wymyśliłem sobie, że zamiast ciężkiego treningu zrobię sobie lekki. Od miesiąca wykonuję głównie ćwiczenia pod trójbój siłowy: ciągi, wyciskanie, przysiady, podrzuty. A teraz niezobowiązująco pomacham ciężarkami. Nagle zrozumiałem, że za coś takiego siłowania się może na mnie obrazić. Wyjdę z szatni i posłyszę gniewne dzwonienie hantli, agresywne szuranie talerzy i jęk zawiedzionej suwnicy. Tego właśnie się boję - obrażonej siłowni.

Na co jego znajomy, Szczepan Twardoch, odpowiedział mu w sekcji komentarzy:

Tak, przyjacielu. Tak to jakoś idzie. Ja dzisiaj pojechałem na trening z tą samą myślą. „Źle spałem. Kiepsko się czuję. Jakoś delikatnie dzisiaj”.

A potem pada pytanie: „to co, machniemy jakieś rundki? Trzy razy po trzy minutki?".

„No, machniemy” - mówię i nie wiem kto to za mnie powiedział, przecież nie ja, mnie się wcale nie chce bić dzisiaj. Machnęliśmy ${ }^{8}$.

Co więcej - mamy również dostęp do informacji o edytowaniu komentarza przez Twardocha i wcześniejszej jego postaci. Dzięki tak rozbudowanym narzędziom system daje bardzo duże możliwości badawcze, w przywołanym przypadku chociażby w kontekście prac nad biografią autora. Bagatelizowanie tak obszernych baz danych może więc wiązać się z odrzuceniem dużej ilości materiału w postaci wypowiedzi o różnorodnym charakterze i różnej tematyce. Co więcej, obecnie ten sposób pracy nad intymistyką może być jedynym sposobem w pełni zgodnym z prawem.

W internecie znajdziemy o wiele więcej źródeł niż dotychczas wymienione w tym artykule. Moglibyśmy zwrócić swoją uwagę na blogosferę, portale rozrywkowe 
(np. YouTube) lub wiele innych wirtualnych lokalizacji. Wszystko zależałoby od materiału, którym dysponowalibyśmy w pracy - od osobistej elektroniki, po loginy i hasła do internetowych kont czy folderów lub plików. Czasy współczesne dają z jednej strony dość rozbudowane możliwości prowadzenia badań nad prywatnością twórców, z drugiej strony trzeba jednak wciąż pamiętać o regulujących takie działania kwestiach prawnych. Dosyć paradoksalnie dużym utrudnieniem może być nietrwałość materiału badawczego. Dane elektroniczne mogą być w nieskończoność powielane, ponadto nie tracą z czasem na jakości. Będą one jednak zawsze polegać na nośnikach, na których są przechowywane. Ciągły rozwój technologiczny sprzyja również kształtowaniu się lepszych rozwiązań w przestrzeni cyfrowej, nasz sprzęt może więc z czasem obniżać swoją wydajność ze względu na wysokie wymagania środowiska, co w konsekwencji powoduje konieczność inwestycji w nowy sprzęt. W ten sposób dane przechowywane na starszym nośniku, o ile nie zostaną przeniesione przez właściciela, najczęściej przepadają. Źródła internetowe zapisywane są z kolei na dużych serwerach, których awaria czy też odłączenie ze względów finansowych może sprawić, że dane zostaną nieodwracalnie utracone.

Dziś trudno nam sobie wyobrazić, by największe internetowe archiwa prywatnych danych, jak Google, Amazon czy nawet Facebook, mogły z dnia na dzień przestać działać, lecz nie można wykluczyć takiej możliwości w przyszłości. O badaniach nad prywatnością współczesnych twórców, z chęcią korzystających z rozwiązań technologicznych, będą prawdopodobnie myśleć badacze nawet nie za dziesięć lat, a dopiero za kilkadziesiąt.

${ }^{1}$ E. Wichrowska, Twoja śmierć. Początki dziennika intymnego w Polsce na przełomie XVIII I XIX wieku, Warszawa 2012.

${ }^{2}$ Intymny portret uczonych. Korespondencja Marii i Stanisława Ossowskich, oprac. E. Neyman, Warszawa 2002, s. 6.

${ }^{3}$ S. Witkiewicz, Listy do żony (1923-1927), Warszawa 2009. 5.02.2019)

${ }^{4}$ Zob. http://prawo.sejm.gov.pl/isap.nsf/DocDetails.xsp?id=WDU19970880553 (dostęp: 5.02.2019).

${ }^{5}$ Zob. http://prawo.sejm.gov.pl/isap.nst/DocDetails.xsp?id=WDU19970890555 (dostęp:

${ }^{6}$ U. Glensk, Siedem grzechów Domostawskiego, 2010, http://kapuscinski.info/siedem-grzechow-domoslawskiego.html (dostęp: 30.01.2019).

${ }^{7} \mathrm{~J}$. Hryszko, W internecie nic nie ginie, https://fundacjapoint.p//2017/02/w-internecienic-nie-ginie/ (dostęp: 30.01.2019).

${ }^{8}$ Ł. Orbitowski, https://www.facebook.com/orbitowski/posts/10215019661299413 (dostęp: 11.02.2019).

Sztuka Edycji 2/2019

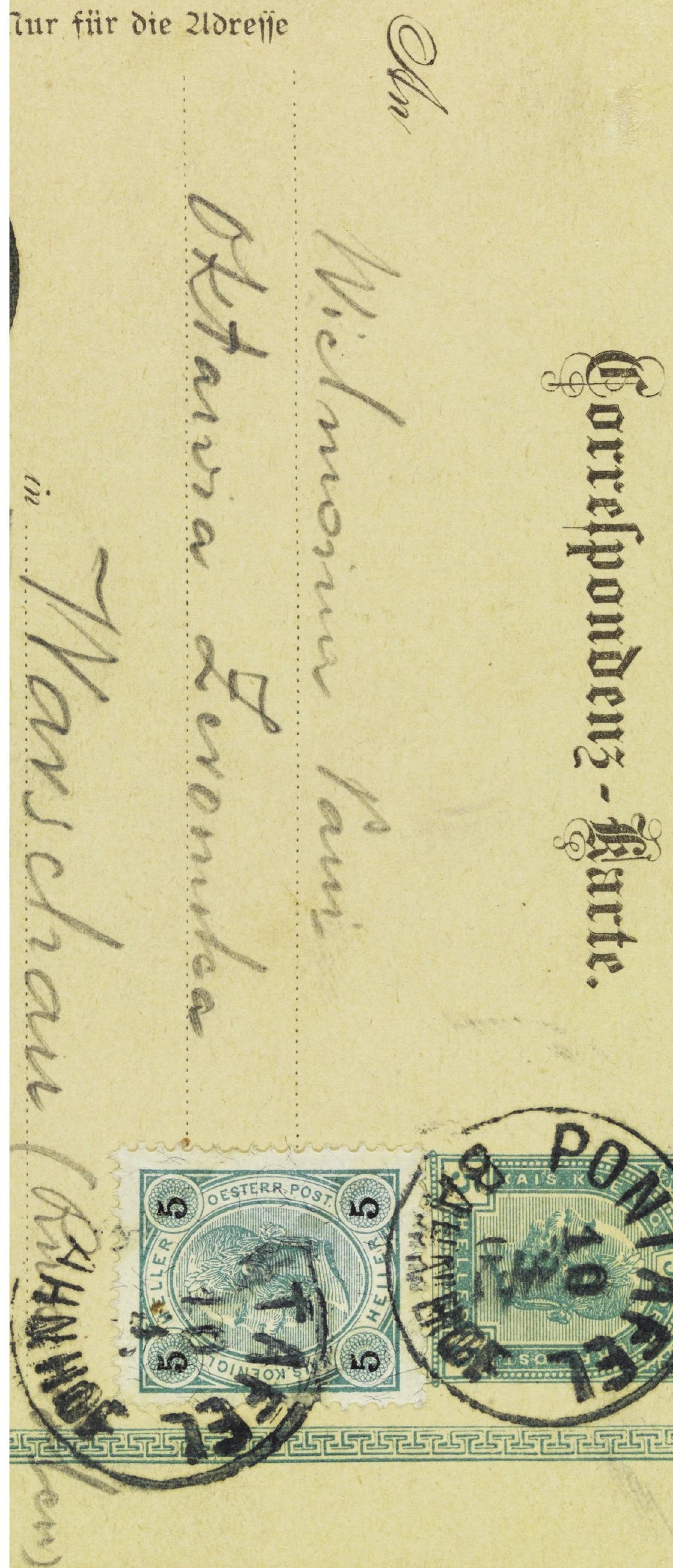

